\title{
Economic Aspects of Carbonates of the Albian Asu River Group in Tse-Kucha Near Yandev, Middle Benue Trough, Nigeria
}

\author{
Anthony Temidayo Bolarinwa ${ }^{1}$, Sunday Ojochogwu Idakwo ${ }^{2} \&$ Alege Tope Shade ${ }^{2}$ \\ ${ }^{1}$ Department of Geology, University of Ibadan, Ibadan, Nigeria \\ ${ }^{2}$ Department of Earth Sciences, Kogi State University, Anyigba, Kogi State, Nigeria \\ Correspondence: Sunday Ojochogwu Idakwo, Department of Earth Sciences, Kogi State University, P.M.B. \\ 1008, Anyigba, Kogi State, Nigeria. E-mail: sunnieeazy@yahoo.com
}

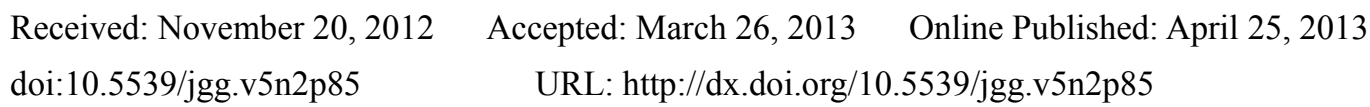

\begin{abstract}
The limestone-shale sequence at Tse-Kucha belongs to the Albian Asu River Group deposited during the first marine transgressive cycle in the Benue Trough. They however vary compositionally in mineralogy and texturally from fine to coarse grained. The compositional disparities between the samples of the limestone imposes corresponding differences in their industrial utilization.

Assessment of the limestone suggested a wider range of industrial utilization beyond the present day application. For example, the highly calcitic limestone (60.04\%) which is characterized by high $\mathrm{CaO}(43.8-53.3 \%)$ and low amount of $\mathrm{MgO}(0.44-1.06 \%)$ constitute suitable raw materials for the cement production, agriculture, metallurgical purification in blast furnace, lime manufacture, chalk, plaster and other filler applications. Apart from silica which varies from $2.1-10.0 \%$, other impurities in the limestone are less than $1 \%$.

In view of the critical need of limestone in more strategic sectors of the economy, such as, iron and steel, agriculture, metallurgical purification/processes in blast furnace, lime manufacture industries, it is recommended that Government should exercise control measures over their exploitation for less profitable ventures. High quality burnt bricks and polished rock slabs could adequately substitute for sandcrete blocks produced from cement, which in many cases unaffordable to the peasants in the community.
\end{abstract}

Keywords: limestone, mineralogy, Tse-Kucha, Asu River Group, Benue Trough

\section{Introduction}

The study area is located in Tse-kucha quarry of Dangote Cement Company Limited Gboko in Benue State of Nigeria (Figure 1). The area falls within the Middle Benue Trough, where the Albian Sediments of the Asu River Group are exposed (Figure 2). It lies within longitudes $8^{\circ} 56^{\prime}$ and $9^{\circ} 00^{\prime} \mathrm{E}$ and latitudes $7^{\circ} 20^{\prime}$ and $7^{\circ} 30^{\prime}$, part of Gboko sheet 271. For many years, several authors have been working on the Cretaceous sediments of the Benue Trough. The Trough is geographically divided into three portions: Lower, Middle and Upper Benue Trough, (Akande et al., 1992; Figure 2). The Trough generally consists of both continental clastic deposits and marine sediments. The origin/evolution and stratigraphy of the trough have been discussed in details by Burke et al. (1970), Grant (1971), Nwachukwu (1972), Olade (1976), Adjihige (1979), Ofoegbu (1984), Maurin et al. (1986). The rift hypothesis was widely favoured in the evolution of the basin (Benkhelil, 1989).

Unlike in the Lower Benue Trough, very few studies have been carried out in the Middle Benue Trough. Published works on the economic aspect of the limestone in the Middle Benue Trough are rare. Petters (1982) worked on the paleontology of the Albian sediments exposed at Yandev. Nair and Ramanathan (1984) studied the sedimentology, stratigraphy and paleogeographic significance of the Albian limestone at Yandev. Abimbola and Akande (1996) studied the petrology, geochemistry and stable isotopes of the carbonate rocks of Arufu-Akwana, Middle Benue Trough while Adekeye and Akande (2002) determined the depositional environment of the carbonates of the Albian Asu River Group around Yandev, Middle Benue Trough.

The strategic location of these carbonate rocks in the Middle Benue Trough where there are towns and cities with high population and industrial conurbations made it important to study the limestone deposit and evaluate it for uses other than cement production, which is the ongoing project in the area. 


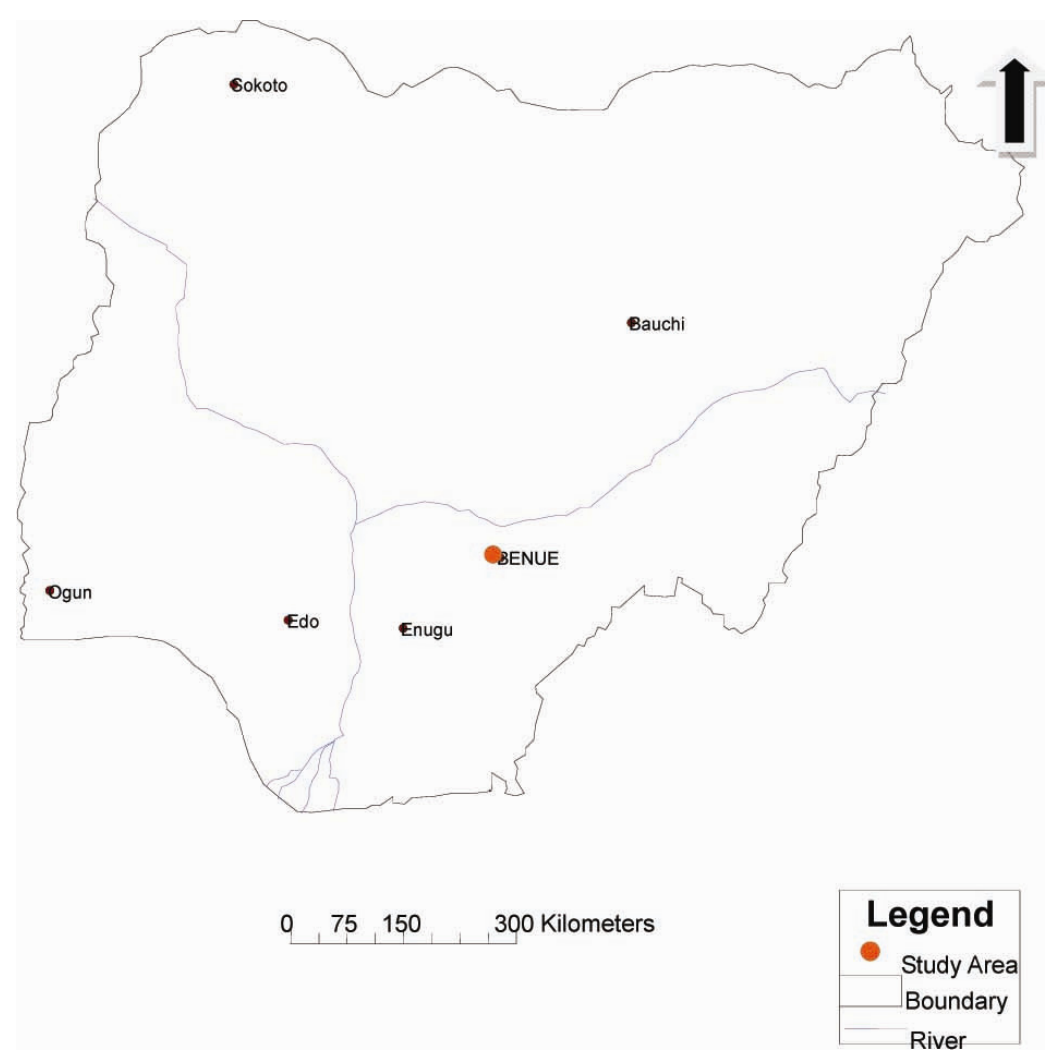

Figure 1. Map of Nigeria showing the Study Area

\section{Geology of the Middle Benue Trough}

Previous workers (Offodile, 1976; Offodile \& Reyment, 1976; Petters, 1982; Obaje et al., 1994) described some aspects of the Upper Cretaceous lithostratigraphic formations in the Middle Benue Trough. Sedimentation began in the Albian with the deposition of interbedded marine shale-limestone sequence of the Asu River Group (Figure 2). These sediments are interpreted as sediments of the first transgressions in the Benue Trough. The sediments are fossiliferous, containing numerous ammonites (Offodile \& Rayment, 1976). Many agglutinated and few calcareous foraminifera taxa were described by Petters (1982) and Ramanathan and Nair (1984). The Asu River Group in the Middle Benue Trough was said to have attained a thickness of ca. $200 \mathrm{~m}$. This formation is overlain by the Awe Formation (Late Albian-Early Cenomanian regressive phase of the first marine transgression). The Awe Formation is ca.100 m thick (Offodile, 1976) and consists of carbonaceous shale, flaggy, medium to coarse grained calcareous sandstones and clay with a coarsening upward sequence. The sediments were deposited in a transitional environment. Overlying this formation is the Keana Formation (Figure 2). It consists of cross bedded, coarse grained, feldsparthic sandstones. The sandstones are generally poorly sorted. According to Offodile (1976) conglomerates, bands of shales and limestones are intercalated towards the top. This Formation is generally not fossiliferous, and the sediments were deposited in fluviatile environments during the Cenomanian regression in the Middle Benue Region. The Makurdi Formation is a lateral equivalent of the Keana Formation in the study area (Figure 2).

The Late Cenomanian-Early Turonian, Eze-Aku Formation overlies the Keana. The Eze-Aku Formation marks the beginning of the second depositional cycle. The sediments deposited consist of calcareous shales, micaceous, fine to medium- grained, friable sandstones and beds of shaly limestone. Elsewhere, outcrops of this formation consists of shales with beds of limestone of variable thickness and colour (Offodile, 1976; Figure 2).

Overlying the Eze-Aku Formation in the upsection is the Awgu sediments which represent the last shallow marine deposits of the second depositional cycle (Turonian-Coniacian). This sediment consists of bluish-grey to dark-black carbonaceous shales, calcareous shale, shaly limestones, siltstones and coal seams (Obaje et al., 1994). The presence of coal suggested a rapid change in the depositional environment. Spores, pollen and dinoflagellates have been recorded from the intercalating coals, coaly shales and carbonaceous shales. The sediments are reported as being fossiliferous consisting predominantly of arenaceous foraminifera and few calcareous taxa and ostracods (Offodile \& Reyment, 1976). 
The youngest formation in the Middle Benue Trough is the Lafia Formation. This Formation represents sediments of the third depositional cycle in the region. The formation unconformably overlies the Agwu Formation (Figure 2). The sediments were deposited in a continental environment and consist of ferruginised sandstones, red loose sands, flaggy mudstone, lignite bands and clays. The Lafia Formation thickens in the southwest direction and is thought to be the lateral equivalent of the Campano-Maastrichtian Enugu Nkporo Formation of the Lower Benue Trough (Offodile, 1976). The Lafia Formation is generally not fossiliferous (Figure 2).

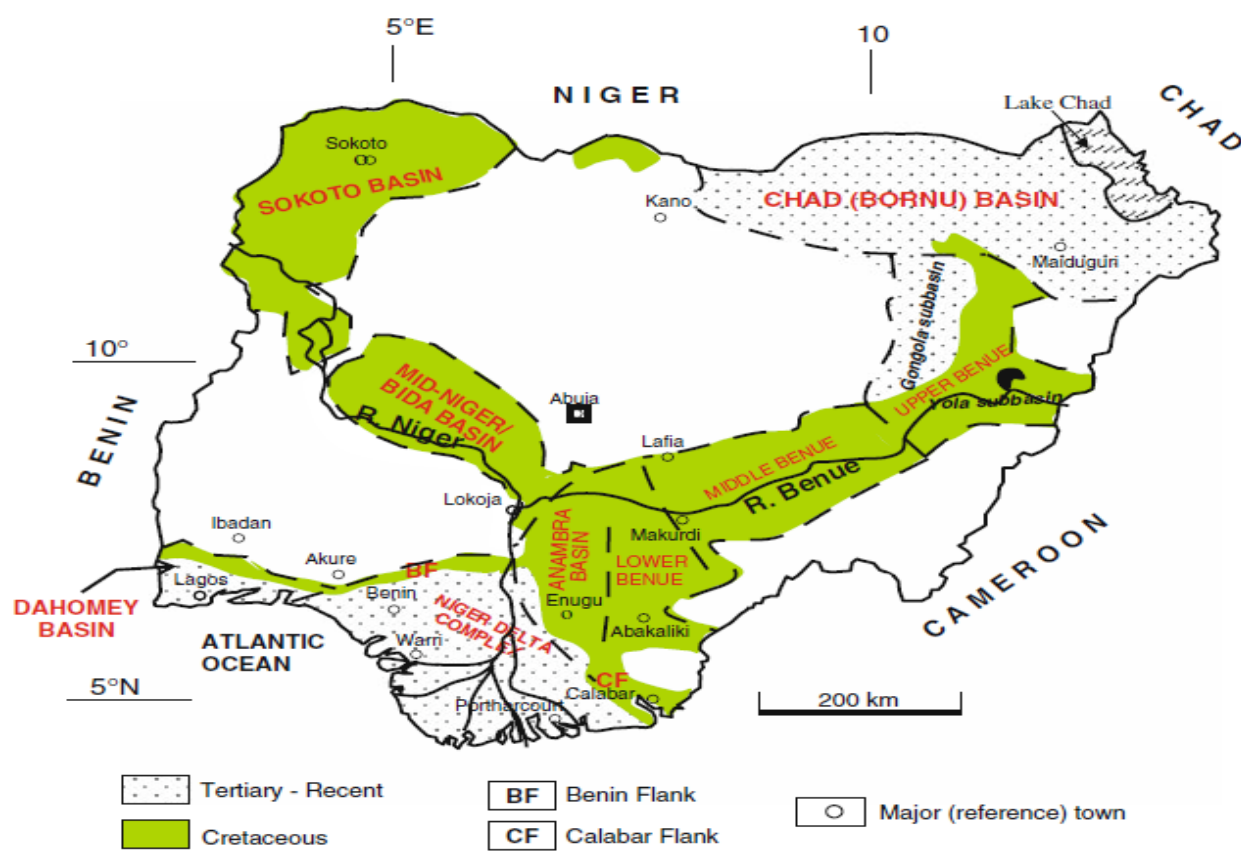

(a)

S

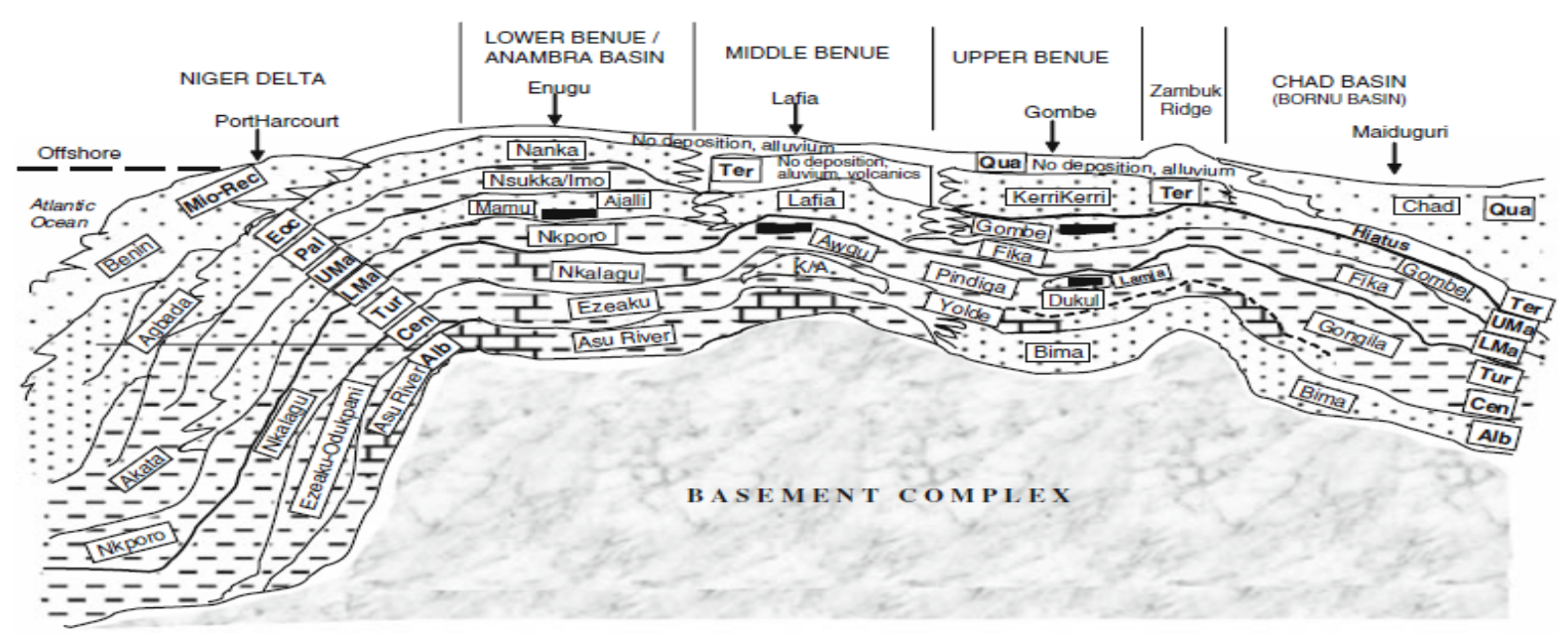

(b)

Figure 2. a) Map of Nigeria showing the Middle Benue Trough and other sedimentary basins of Nigeria;

b) Idealized N-S stratigraphic cross-section across the Chad Basin-Benue Trough-Niger Delta depicting a connected trans-Atlantic Sea way between the South Atlantic and the Tethys Sea during the Coniacian- Turonian (After Obaje, 2009) 


\section{Materials and Methods of Study}

Fifteen (15) representative samples were collected from different parts of the benches as exposed at a quarry site in Tse-Kucha village (Figures 4 and 5). The number of samples was determined by the outcropping pattern in the respective bench.

Samples were prepared for petrographic studies at the Department of Geology, University of Ibadan, Ibadan, Nigeria. The minerals present in the thin sections were identified (Figure 6). Powdered samples were prepared for X-ray diffraction studies. These samples were analysed at ACME Analytical Laboratories Ltd, Vancouver. Canada. Diffraction peaks of the minerals present were identified using their characteristic set of d-spacings. The relative proportions of the minerals were calculated using the area method as described by Carroll and Dorothy (1970).

Major and trace element composition of the limestone samples were determined using Induced Coupled Plasma-Emission Spectrometry (ICP-ES) and Induced Coupled Plasma-Mass Spectrometry (ICPMS) at ACME Analytical Laboratories Ltd, Vancouver. Canada.

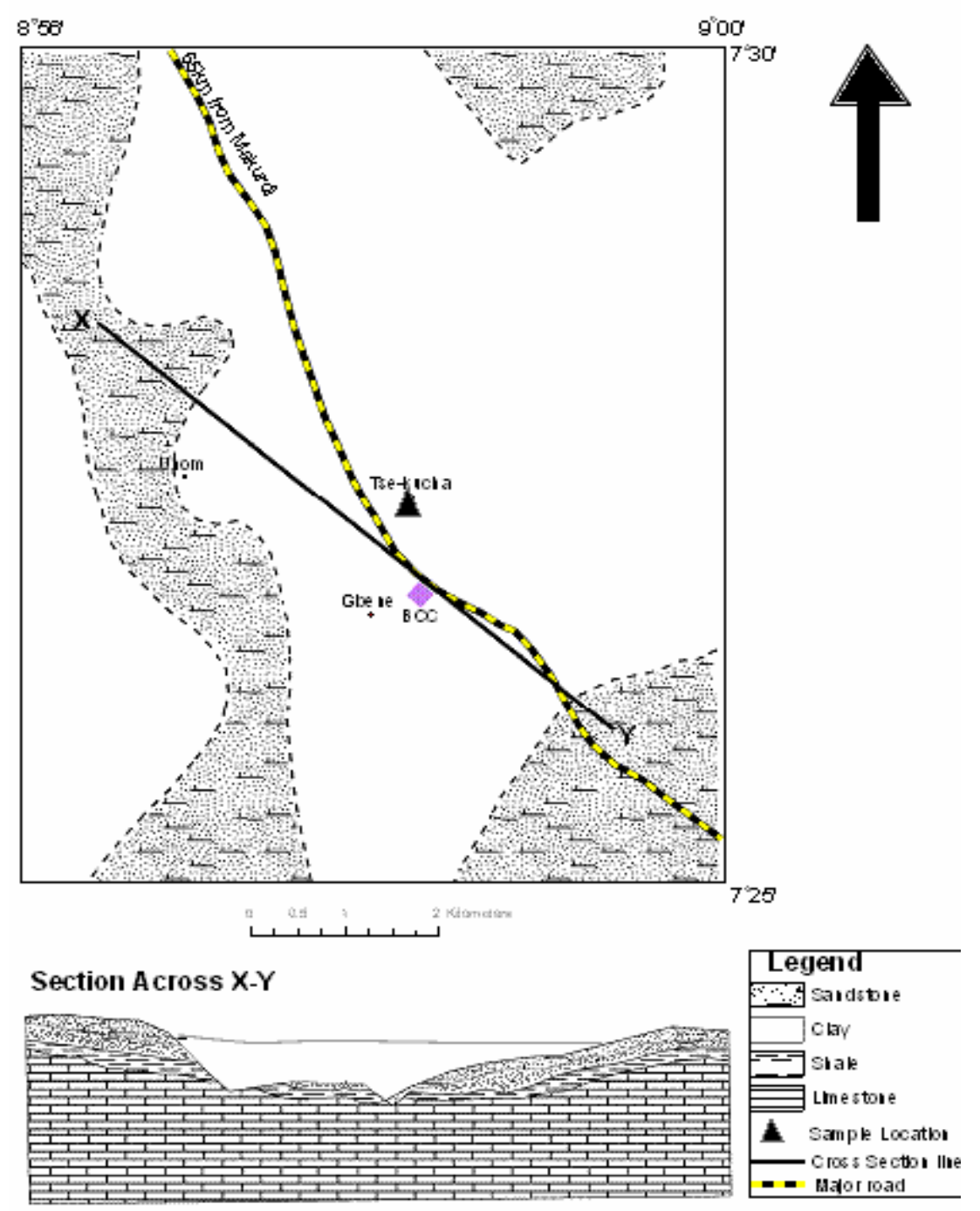

Figure 3. Geological map of Tse-Kucha area 


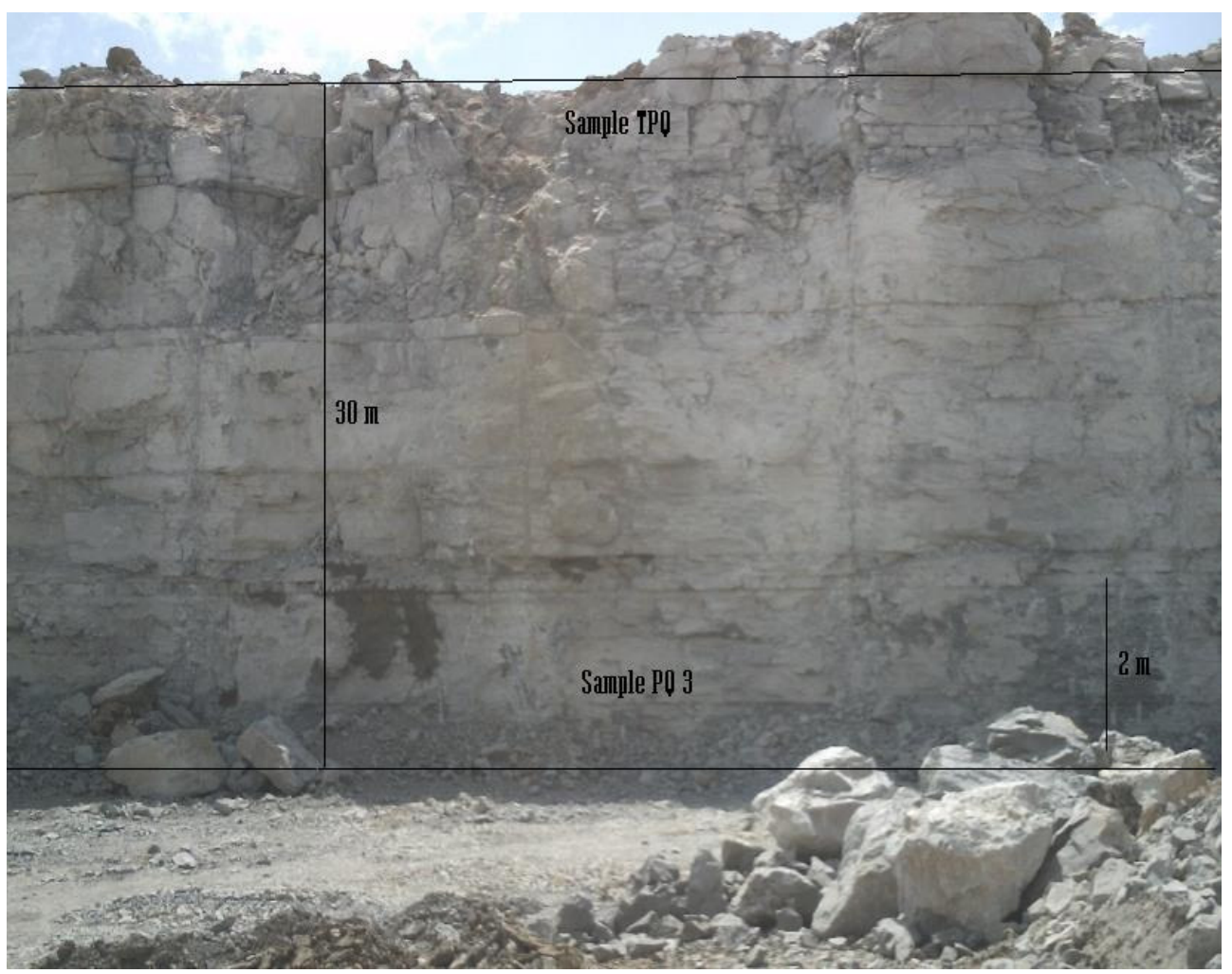

Figure 4. Photograph of Bench PQ at Tse-Kucha Quarry showing the vertical height of the Limestone of $30 \mathrm{~m}$, shale intercalation of $2 \mathrm{~m}$ and sampling points TPQ \& PQ3

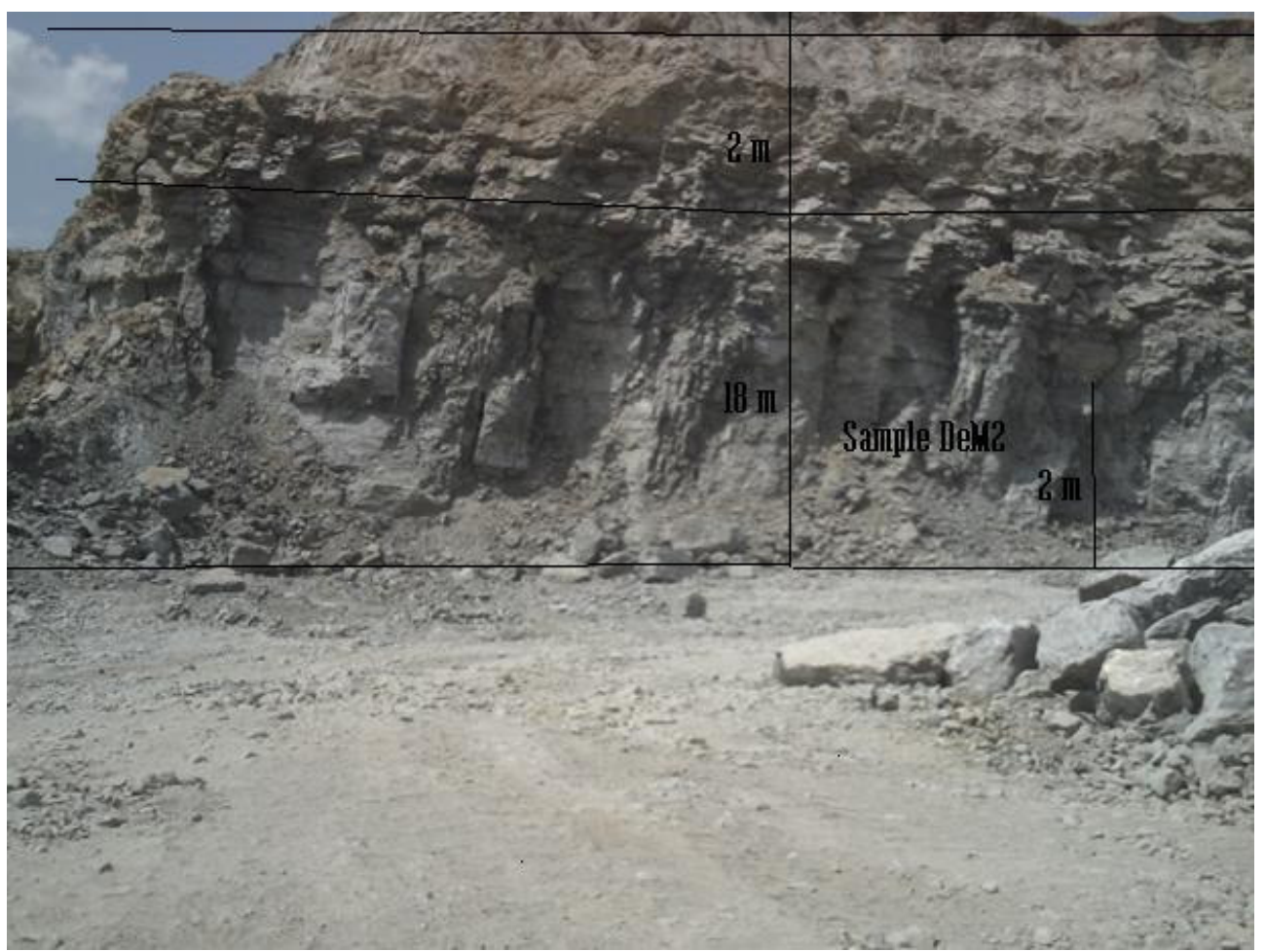

Figure 5. Photograph of Bench DE Main at Tse-Kucha Quarry showing the vertical height of the Limestone of $18 \mathrm{~m}$, sandstone of $2 \mathrm{~m}$, shale intercalation of $2 \mathrm{~m}$ and sampling point DE Main 2 


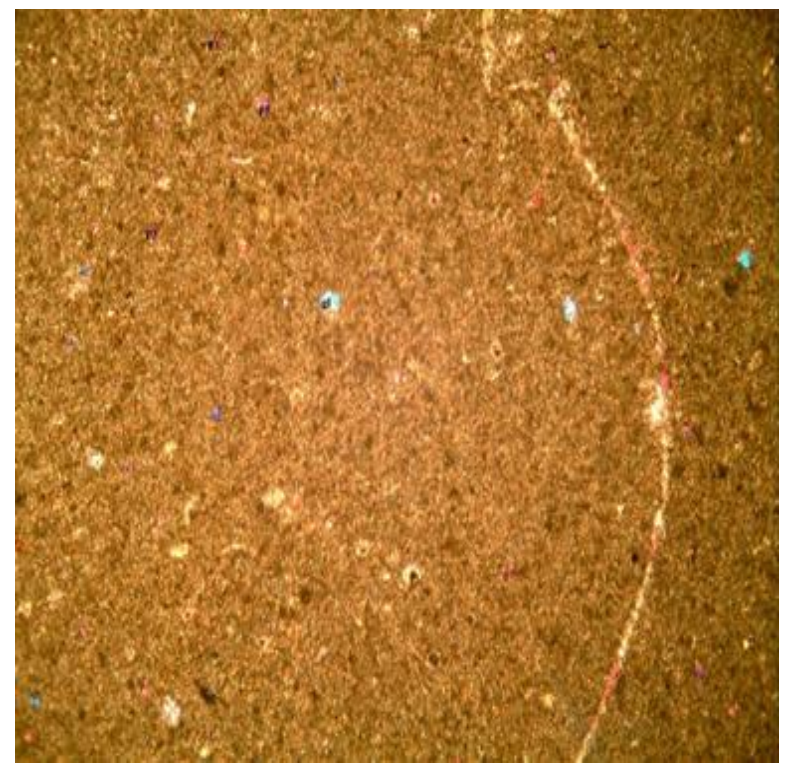

A

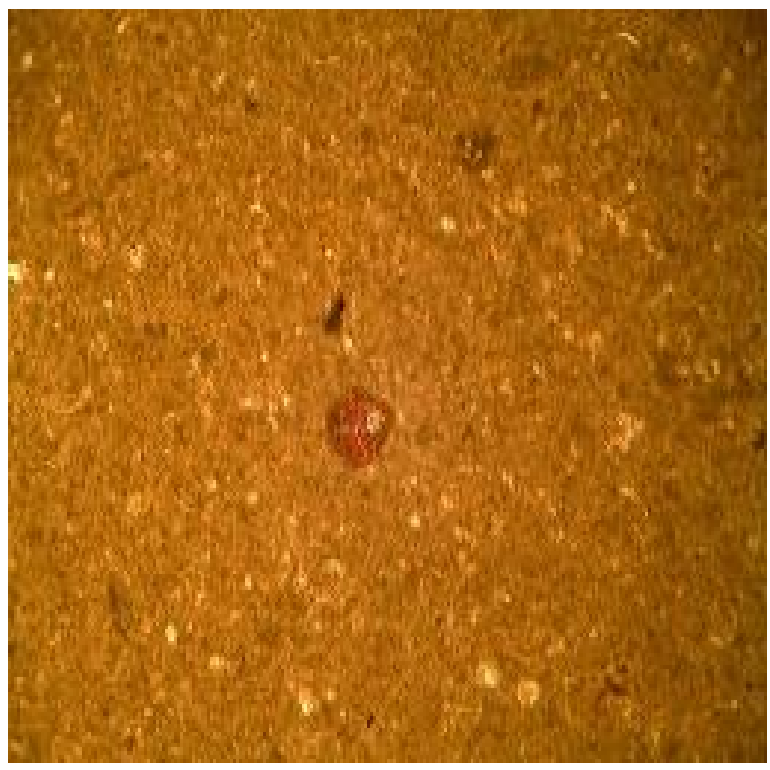

B

Figure 6. Photomicrograph showing a detrital pyrite, Py (Reddish brown) and glauconite, gl (Bluish). (Sample DE North $2=$ A and DE South $1=$ B) (Mag. x40 $\mu \mathrm{m})$

\section{Results and Discussion}

\subsection{Mineralogy}

Petrographic examinations and interpretation of diffractograms (Figures 6, 7 and 8) show that calcite $\left(\mathrm{CaCO}_{3}\right)$ is the dominant mineral in the Tse-Kucha limestone. It constitutes about $60.04 \%$. Quartz and pyrite are about 16.0 and $4.0 \%$ respectively. The compositional disparities between the benches of limestone impose corresponding differences in their petrogenesis and industrial utilization. For example, the highly calcitic limestone is a suitable raw material in cement, agriculture (liming of soils and fish ponds), paint, poultry and metallurgical purification processes in the steel industry (Figure 7).

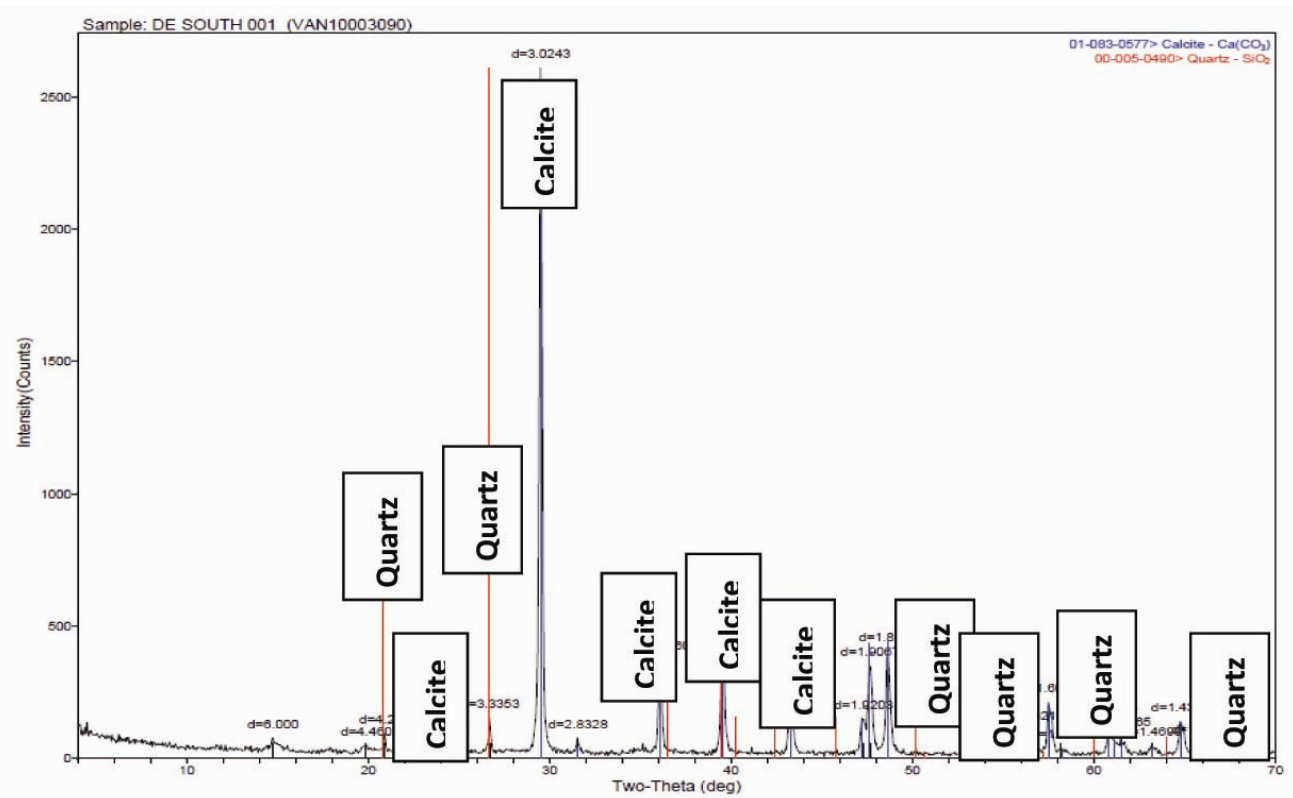

Figure 7. Diffractogram of the limestone from DE South Bench of the open quarry at Tse-Kucha near Yandev in Gboko 


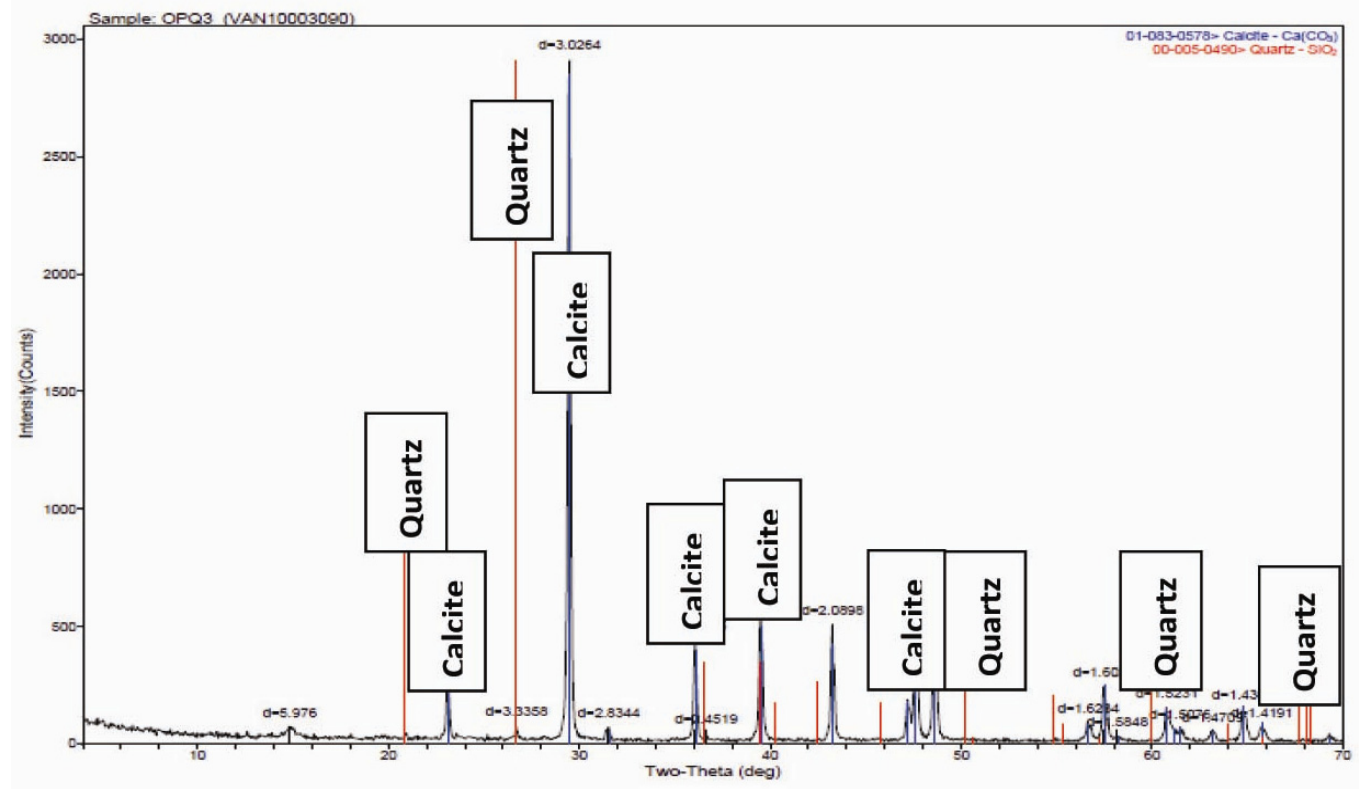

Figure 8. Diffractogram of the limestone from PQ Bench of the open quarry at Tse-Kucha in Gboko

\subsection{Geochemistry}

Major elemental oxides shown in Table 1, Figure 9 and 10 showed that $\mathrm{CaO}$ concentrations range between 43.83-53.32 with mean value of $48.16 \%$. The silica $\mathrm{SiO}_{2}$ contents range between $2.11-10.00 \%$ with a mean value of $6.39 \%$ and $\mathrm{Fe}_{2} \mathrm{O}_{3(\mathrm{t})}$ between $0.66-2.13$ with mean of $1.43 \%, \mathrm{MgO}$ and $\mathrm{Al}_{2} \mathrm{O}_{3}$ content vary between 0.44-1.06 and $0.49-4.02$ with mean values of $0.70 \%$ and $2.20 \%$ respectively.

A comparison of these results with the chemical specifications of a number of industries that utilize raw limestone is discussed below.

Table 1. Major element compositions (wt \% oxide) of limestones of Tse-Kucha area near Yandev

\begin{tabular}{|c|c|c|c|c|c|c|c|c|c|c|c|c|c|c|c|}
\hline Samples & TPQ & PQ3 & QR3 & $\mathrm{O} 2$ & S3 & R3 & $\begin{array}{l}\text { DE } \\
\text { N1 }\end{array}$ & $\begin{array}{l}\mathrm{DE} \\
\mathrm{N} 2\end{array}$ & $\begin{array}{l}\mathrm{DE} \\
\mathrm{N} 3\end{array}$ & $\begin{array}{l}\mathrm{DE} \\
\mathrm{S} 1\end{array}$ & $\begin{array}{l}\mathrm{DE} \\
\mathrm{S} 2\end{array}$ & $\begin{array}{l}\text { DE } \\
\text { S3 }\end{array}$ & $\begin{array}{l}\mathrm{DE} \\
\mathrm{M} 2\end{array}$ & Range & Mean \\
\hline $\mathrm{SiO}_{2}$ & 6.99 & 3.16 & 2.11 & 6.91 & 6.07 & 10.00 & 4.77 & 8.43 & 6.62 & 8.20 & 8.02 & 4.41 & 7.40 & $2.11-10$ & 6.40 \\
\hline $\mathrm{Al}_{2} \mathrm{O}_{3}$ & 2.02 & 0.88 & 0.49 & 2.00 & 2.49 & 4.02 & 1.31 & 2.24 & 2.01 & 3.04 & 3.03 & 1.81 & 2.96 & $0.49-4.02$ & 2.20 \\
\hline $\mathrm{Fe}_{2} \mathrm{O}_{3(\mathrm{t})}$ & 1.16 & 0.66 & 0.87 & 1.33 & 1.57 & 1.71 & 2.13 & 1.88 & 1.74 & 1.65 & 2.04 & 0.77 & 1.11 & $0.66-2.13$ & 1.40 \\
\hline $\mathrm{MgO}$ & 0.72 & 0.44 & 0.48 & 0.72 & 0.79 & 0.97 & 0.91 & 0.65 & 0.63 & 0.82 & 1.06 & 0.61 & 0.71 & $0.44-1.06$ & 0.70 \\
\hline $\mathrm{CaO}$ & 47.82 & 52.52 & 53.32 & 48.03 & 47.76 & 43.83 & 49.63 & 46.34 & 47.90 & 45.52 & 45.98 & 50.1 & 47.33 & $43.83-53.32$ & 48.20 \\
\hline $\mathrm{Na}_{2} \mathrm{O}$ & 0.14 & 0.05 & 0.03 & 0.14 & 0.07 & 0.15 & 0.11 & 0.13 & 0.08 & 0.03 & 0.09 & 0.06 & 0.07 & $0.03-0.15$ & 0.09 \\
\hline $\mathrm{K}_{2} \mathrm{O}$ & 0.45 & 0.19 & 0.10 & 0.44 & 0.55 & 0.89 & 0.27 & 0.48 & 0.43 & 0.64 & 0.65 & 0.41 & 0.69 & $0.1-0.89$ & 0.48 \\
\hline $\mathrm{TiO}_{2}$ & 0.09 & 0.05 & 0.03 & 0.09 & 0.13 & 0.20 & 0.09 & 0.12 & 0.11 & 0.15 & 0.15 & 0.09 & 0.18 & $0.03-0.2$ & 0.11 \\
\hline $\mathrm{P}_{2} \mathrm{O}_{5}$ & 0.07 & 0.05 & 0.07 & 0.07 & 0.13 & 0.13 & 0.19 & 0.08 & 0.08 & 0.10 & 0.11 & 0.17 & 0.23 & $0.05-0.23$ & 0.11 \\
\hline $\mathrm{MnO}$ & 0.07 & 0.05 & 0.05 & 0.07 & 0.05 & 0.05 & 0.06 & 0.11 & 0.09 & 0.05 & 0.06 & 0.04 & 0.04 & $0.04-0.97$ & 0.13 \\
\hline LOI & 40.40 & 41.80 & 42.40 & 40.10 & 39.90 & 37.90 & 40.40 & 39.40 & 40.20 & 39.70 & 38.70 & 41.50 & 39.20 & $37.90-42.40$ & 40.12 \\
\hline Total & 99.92 & 99.89 & 99.95 & 99.91 & 99.47 & 99.90 & 99.91 & 99.91 & 99.89 & 99.90 & 99.90 & 99.93 & 99.92 & & \\
\hline
\end{tabular}

N---North

S---South

M---Main 
Table 2. Trace elemental concentrations of Tse-Kucha Limestone

\begin{tabular}{llllllllllllllll}
\hline Samples & TPQ & PQ3 & QR3 & O2 & S3 & R3 & $\begin{array}{l}\text { DE } \\
\text { N1 }\end{array}$ & $\begin{array}{l}\text { DE } \\
\text { N2 }\end{array}$ & $\begin{array}{l}\text { DE } \\
\text { N3 }\end{array}$ & $\begin{array}{l}\text { DE } \\
\text { S1 }\end{array}$ & $\begin{array}{l}\text { DE } 2 \\
\text { S3 }\end{array}$ & $\begin{array}{l}\text { DE } \\
\text { M2 }\end{array}$ & DE & Range & Mean \\
\hline $\mathrm{Pn}$ & 5 & 2 & 3 & 6 & 5 & 9 & 15 & 8 & 3 & 9 & 8 & 3 & 3 & $2-15$ & 6.31 \\
$\mathrm{Rb}$ & 18 & 7 & 16 & 21 & 27 & 72 & 24 & 54 & 10 & 35 & 54 & 10 & 10 & $7-72$ & 27.54 \\
$\mathrm{Sr}$ & 22 & 10 & 5 & 22 & 29 & 49 & 13 & 35 & 19 & 33 & 35 & 19 & 33 & $5-49$ & 25.28 \\
$\mathrm{Zr}$ & 503 & 340 & 355 & 518 & 655 & 578 & 552 & 620 & 422 & 508 & 620 & 422 & 435 & $340-655$ & 502.74 \\
$\mathrm{Ce}$ & 19 & 16 & 8 & 34 & 21 & 45 & 27 & 27 & 19 & 232 & 23 & 19 & 38 & $8-232$ & 41.72 \\
$\mathrm{Ba}$ & 26 & 541 & 14 & 28 & 3821 & 36 & 28 & 69 & 51 & 32 & 34 & 51 & 26 & $14-3821$ & 365.92 \\
\hline
\end{tabular}

N---North

S---South

M---Main

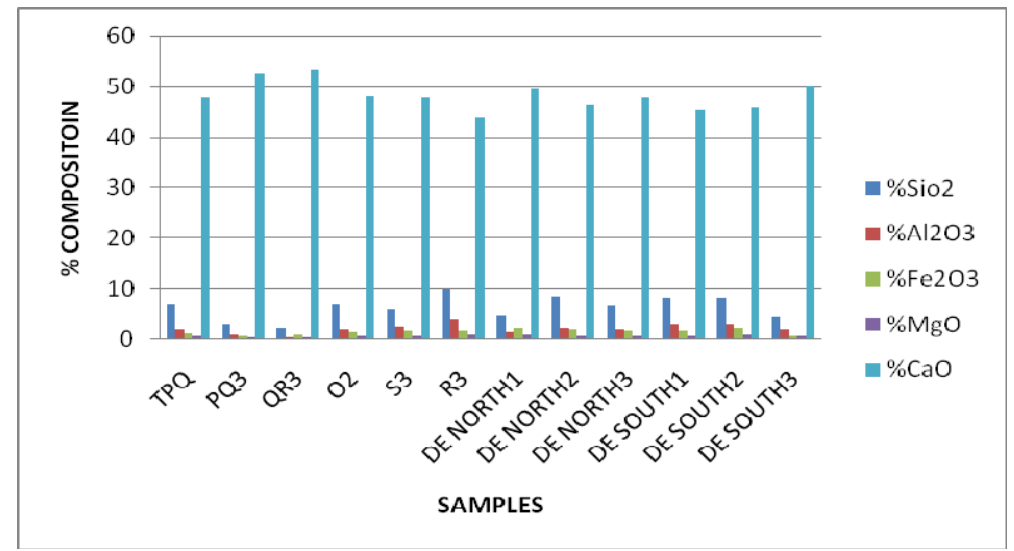

Figure 9. Percentage composition of the Oxides in the limestone of Tse-Kucha area

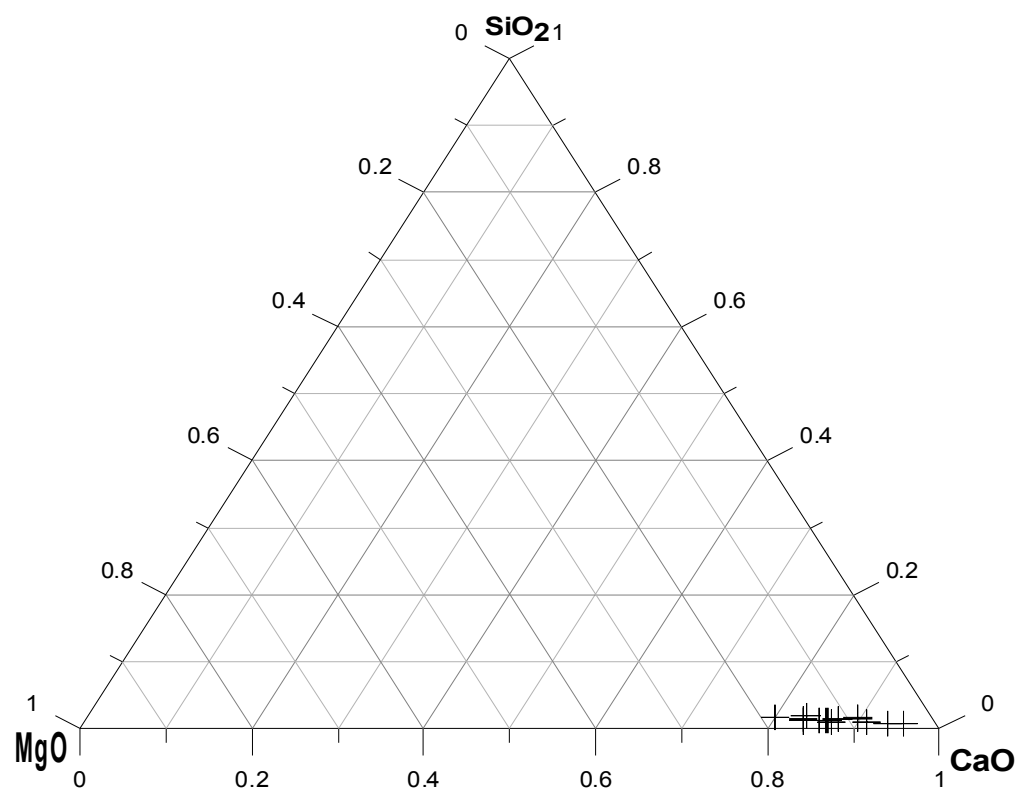

Figure 10. Ternary Diagram showing the Major oxides of Gboko limestone Sampled from Tse-Kucha near Yandev in Gboko 


\section{Iron and Steel Industry}

Limestone can be mixed with iron ore to remove the impurities in the iron ore. Limestones form a substance known as slag when mixed with iron ore. The slag is separated from the iron, and taken away, leaving pure molten iron which can be made into steel alloy.

\subsection{Blast Furnace (B.F.)}

The initial reaction is the thermal decomposition of calcium carbonate to form Calcium oxide (Lime):

$$
\mathrm{CaCO}_{2}(\mathrm{~s}) \rightarrow \mathrm{CaO}(\mathrm{s})+\mathrm{CO}_{2}(\mathrm{~g})
$$

This is followed by the reaction of lime with sandy impurities $\left(\mathrm{SiO}_{2}\right)$ in the iron ore to form calcium silicate:

$$
\mathrm{CaO}(\mathrm{s})+\mathrm{SiO}_{2}(\mathrm{~s}) \rightarrow \mathrm{CaSiO}_{3}(\mathrm{l})
$$

Comparing the results of the test samples from Tse-kucha to the industrial specifications on Table 4, most of the samples were found to meet the specifications for use in steel plants. The $\mathrm{CaO}$ content is high (43.8-53.3\%) while the $\mathrm{SiO}_{2}(2.11-10 \%)$ and sulphur contents are low. The specification for limestone to be used in blast furnace include about $90 \% \mathrm{CaCO}_{3}, 6.0-11.5 \%$ total $\mathrm{SiO}_{2}+\mathrm{Al}_{2} \mathrm{O}_{3}$ and $4 \% \mathrm{MgO}$. Sulphur and phosphorous contents are expected to be negligible.

Table 3. Analytical Data of other Comparable Limestones

\begin{tabular}{llllllll}
\hline & 1 & 2 & 3 & 4 & 5 & 6 & 7 \\
\hline $\mathrm{CaO}$ & 48.20 & 46.88 & 49.74 & 52.17 & 54.54 & 55.21 & 52.48 \\
$\mathrm{MgO}$ & 0.70 & 1.99 & 0.99 & 1.77 & 0.59 & 0.46 & 0.59 \\
$\mathrm{Co}_{2}$ & 40.12 & 36.57 & - & 44.97 & 42.90 & 43.73 & 41.85 \\
$\mathrm{SiO}_{2}$ & 6.40 & 9.78 & 5.90 & 0.53 & 0.70 & 0.42 & 2.38 \\
$\mathrm{Al}_{2} \mathrm{O}_{3}$ & 2.20 & 1.48 & 1.30 & 0.07 & 0.68 & 0.13 & 1.57 \\
$\mathrm{Fe}_{2} \mathrm{O}_{3}$ & 1.40 & 2.20 & 0.77 & 0.04 & 0.08 & 0.05 & 1.56 \\
$\mathrm{So}_{3}$ & - & - & - & - & 0.31 & 0.01 & - \\
$\mathrm{P}_{2} \mathrm{O}_{5}$ & 0.11 & - & - & - & - & - & - \\
$\mathrm{Na}_{2} \mathrm{O}$ & 0.09 & 0.05 & - & 0.19 & 0.16 & - & - \\
$\mathrm{K}_{2} \mathrm{O}$ & 0.48 & 0.01 & - & 0.13 & - & - & - \\
$\mathrm{MnO}$ & 0.13 & - & - & 0.07 & - & - & - \\
$\mathrm{TiO}_{2}$ & 0.11 & - & - & 0.01 & - & - & - \\
\hline
\end{tabular}

1-Tse-kucha limestone (This study).

2-Gboko limestone (Bejide, 2000).

3-Nkalagu (Philips et al., 2009).

4-Middle Belt Zone (Abdulrahman \& Ayuba, 2007).

5- Idiana high calcium stone.

6-Virginia High Calcium Stone.

7-Kansas Cretaceous High Calcium (5-7After Boynton, 1960). 
Table 4. Industrial specifications of limestone (\%) for blast furnace, steel melting and glass industries

\begin{tabular}{lllllll}
\hline & 1 & 2 & 3 & 4 & 5 & 6 \\
\hline $\mathrm{CaO}$ & 48.16 & $42.00-47.5$ & $47.5-50$ & - & 54.85 & 54.85 \\
$\mathrm{CaCO}_{3}$ & 88.28 & - & - & 94.50 (Min) & & - \\
$\mathrm{CaCO}_{3}+\mathrm{MgCO}_{3}$ & - & - & - & 97.50 & - & - \\
$\mathrm{Al}_{2} \mathrm{O}_{3}$ & 2.18 & $1.30-2.00$ & 1.30 & $1.50($ max) & 0.35 & $0.30-0.40$ \\
$\mathrm{Fe}_{2} \mathrm{O}_{3}$ & 1.43 & - & - & - & - & 0.10 \\
$\mathrm{SiO}_{2}$ & 6.39 & $5.00-10.00$ & $4.0-5.30$ & 1.50 & - & - \\
$\mathrm{MgO}$ & 0.73 & $4.00-8.00$ & $3.50-4.00$ & - & 0.80 & $0.70-0.83$ \\
Total insoluble & - & $6.50-12.00$ & 5.12 .00 & - & - & 12.00 \\
\hline
\end{tabular}

1-Limestone samples from Tse-kucha village (This study).

2-Specification of limestone for Blast furnace after Umeshwar, 2003.

3-Specification of limestone for Steel Melting Shop after Umeshwar, 2003.

4-Specification of limestone for India glass industry after Umeshwar, 2003.

5-Specification of limestone for flat glass manufacturing after Emefurieta and Ekuajemi, 1995.

6-Specification of limestone in \% for container glass after Harben, 1995.

\subsection{Steel Melting Shop (SMS)}

The chemical compositions of most of the limestone samples analyzed were not within the range of the specifications for steel melting shop. The $\mathrm{SiO}_{2}$ content is too high though the $\mathrm{CaO}$ content is within the recommended value (Table 4).

\subsection{Glass Industry}

The Tse-Kucha limestone could not serve as a raw material in the production of glass because of the lower amount of $\mathrm{CaO}$ compared to the recommended value (Table 4).

For colourless glass high purity of limestone is needed with organic matter of 0.3 at maximum.

As per Indian standard 997-1937, FeO content should not be more than $0.50 \%$ in calcite, 0.01 in limestone.

\subsection{Chemical Industry}

Coral limestone and limeshell, being comparatively purer, are preferred in the chemical industry as a mineral supplement in cattle feed. The carbonates must be low in silica and alumina. Extremely low in fluorine and contains no arsenic (Department, Mineral and Energy, Republic of South Africa, 2003).

\subsection{Fertilizer Industry}

For the production of fertilizer, organic matter and sulpur should be negligible (Umeshwer, 2003). The total $\mathrm{CaCO}_{3}$ content however should be at least $84.0 \%$. It is believed that the $\mathrm{SiO}_{2}$ content of the Tse-kucha limestone could be reduced through appropriate beneficiation from $6.3 \%$ to less than $5.0 \%$ which is the maximum recommended value for fertilizer production (Table 6).

\subsection{Lime Manufacture}

For the production of chalk and plaster, $\mathrm{SiO}_{2}$ may be $10 \%$ or more but $\mathrm{MgO}$ should be negligible. The chemical composition of the Tse-kucha limestone is within the industrial specification for both chalk and plaster. However solid and highly compact variety would be required.

\subsection{Agriculture}

Nitrogen compounds are the source of soil acidity. In addition nitrates are a major factor in the leaching of other nutrient salts from soils. These are then replaced by the available hydrogen ions, rendering the soil even more acidic. Apart from supplying nutrients, a desirable fertilizer should offset changes in soil acidity brought about by nitrification. Calcium carbonate neutralizes soil acidity when applied on the soil surface (Blevins et al., 1978; Conyers et al., 2003; Caires et al., 2005). 
The relatively impure samples which could not meet the requirement for chemical and other applications earlier stated can be used in the liming of soils (Emofurieta \& Ekuajemi, 1995).

It is therefore, apparent that the use of limestone for cement production only may not be entirely beneficial to the industrial growth of other sectors, such as, steel making shop, chemical, fertilizer and lime production. More fertilizer production companies should be setup to utilize the considerable reserves of limestone and phosphate in the Cretaceous and Tertiary sedimentary basins of Nigeria.

Table 5. Industrial specifications of limestone (\%) as raw materials for chemicals industries

\begin{tabular}{lllll}
\hline & 1 & 2 & 3 & 4 \\
\hline $\mathrm{CaO}$ & 48.16 & $54.00(\max )$ & $53.00(\max )$ & $54.00(\mathrm{Min})$ \\
$\mathrm{CaCO}_{3}$ & 88.28 & - & - & - \\
$\mathrm{Al}_{2} \mathrm{O}_{3}$ & 2.18 & - & - & - \\
$\mathrm{Fe}_{2} \mathrm{O}_{3}$ & 1.43 & $0.15(\max )$ & - & $0.25(\mathrm{Max})$ \\
$\mathrm{Al}_{2} \mathrm{O}_{3}+\mathrm{Fe}_{2} \mathrm{O}_{3}$ & 3.61 & - & - & - \\
$\mathrm{SiO}_{2}$ & 6.39 & - & - & $1.00(\mathrm{Max})$ \\
$\mathrm{MgO}$ & 0.73 & $2(\max )$ & $1.00(\max )$ & $0.80(\mathrm{Max})$ \\
$\mathrm{CO}$ & - & - & $42.00(\min )$ & - \\
$\mathrm{As}(\mathrm{ppm})$ & 6.68 & - & - & - \\
$\mathrm{Pb}(\mathrm{ppm})$ & 6.25 & 45 & - & - \\
$\mathrm{LOI}$ & 40.12 & $\mathrm{Mn}_{2} \mathrm{O}_{2}=0.06(\max )$ & $\mathrm{SiO}_{2}+\mathrm{Al}_{2} \mathrm{O}_{3}+\mathrm{Fe}_{2} \mathrm{O}_{3}=$ & $\mathrm{P}=0.5(\max )$, \\
$\mathrm{Remark}$ & & & $3(\max )$ & $\mathrm{S}=0.01(\max )$ \\
\hline
\end{tabular}

1-Limestone samples from Tse-kucha village (This study).

2-Specification of limestone for Bleaching powder after Umeshwar, 2003.

3-Specification of limestone for Caustic soda after Umeshwar, 2003.

4-Specification of limestone for Calcium carbide after Umeshwar, 2003.

Table 6. Industrial specifications of limestone (\%) as raw materials for fertilizer, textile and ceramic industries

\begin{tabular}{lllll}
\hline & 1 & 2 & 3 & 4 \\
\hline $\mathrm{CaO}$ & 48.16 & - & - & - \\
$\mathrm{CaCO}_{3}$ & 88.28 & 84.00 (Min) & 94.00 (Min) & - \\
$\mathrm{CaCO}_{3}+\mathrm{MgCO}_{3}$ & - & - & - & 97.00 (Min) \\
$\mathrm{Al}_{2} \mathrm{O}_{3}$ & 2.18 & - & - & - \\
$\mathrm{Fe}_{2} \mathrm{O}_{3}$ & 1.43 & - & - & 0.30 (Max) \\
$\mathrm{Al}_{2} \mathrm{O}_{3}+\mathrm{Fe}_{2} \mathrm{O}_{3}$ & 3.61 & - & 2.00 (Max) & - \\
$\mathrm{SiO}_{2}$ & 6.39 & 5.00 & 2.50 (Max) & 0.10 (Max) \\
$\mathrm{MgO}^{\mathrm{Humidity}}$ & 0.73 & - & 3.00 (Max) & 3.00 (Max) \\
\hline
\end{tabular}

1-Results of analysed limestone samples from Tse-kucha village (This Study).

2-Specification of limestone for fertilizer production after Umeshwar, 2003.

3-Specification of limestone for textile production Umeshwar, 2003.

4-Specification of limestone for ceramic production after Umeshwar, 2003. 


\section{Conclusions}

The limestone deposit of Tse-kucha area in the Middle Benue Trough was found to be calcitic in composition. This was supported by the chemical composition which showed the dominance of $\mathrm{CaO}$ and loss on ignition (LOI) which is mainly $\mathrm{CO}_{2}$.

Industrial evaluation of the limestone showed that it can be used as a raw material for the production of fertilizer, lime, chemicals, metallurgical purification in blast furnace, as well as, chalk and plaster apart from the conventional use in cement production.

This sundry application would promote economic growth in the area of occurrence and the country at large. Government should therefore exercise control over the use of limestone for less profitable ventures.

\section{References}

Abdulraman, A. A., \& Ayuba, A. M. (2007). Anaysis of Limestone Samples Sourced from the Middle Belt Zone of Nigeria. International Journal of Pure and Applied Sciences, 1(2), 1-8.

Abimbola, A. F., \& Akande, S. O. (1996). Alteration of carbonate host rocks of the Fluorite-Lead-Zinc mineralization at Arufu and Akwana. Middle Benue Trough, Nigeria. Journal of Mining and Geology, 32, 16-25.

Adekeye, O. A., \& Akande, S. O. (2002). Depositional Environment of Carbonates of the Albian Asu River Groups Around Yandev, Middle Benue Trough, Nigeria. Journal of Mining and Geology, 38(2), 91-101. http://dx.doi.org/10.4314/jmg.v38i2.18779

Adeleye, D. R. (1975). Nigeria Late Cretaceous Stratigraphy and Paleogeography. Bulletin AAPG, 59(2), 2302-2313.

Adighije, C. (1979). Gravity Field of the Benue Trough, Nigeria. Nature Physics and Science, 282, $199-201$. http://dx.doi.org/10.1038/282199a0

Akande, S. O., Hoffknecht, A., \& Erdtmann, B. D. (1992). Environmental of Ore formation and Anchizonal Metamorphism in Pb-Zn-Ba-F Deposits of the Benue Trough, Nigeria. Geologie en Mijnbouw, 71, 131-144.

Akande, S. O., Horn, E. E., \& Reutel, C. (1988). Mineralogy, Fluid Inclusion and Genesis of the Arufu and Akwana Pb-Zn-F Mineralization, Middle Benue Trough, Nigeria. Journal of African Earth Science, 7, 167-180. http://dx.doi.org/10.1016/0899-5362(88)90063-2

Bejide. (2000). The Pore System Geometry and Diagenesis of the Albian Gboko limestone (Asu River Group) Middle Benue Trough, Nigeria (Unpublished M.Sc Research project).

Bell. J. P. (1963). A Summary of the Pricipal limestone and Marble Deposits of Nigeria. Geological Survey. Nigeria, Rep., 1192.

Benkhelil, J. (1989). The Origin and Evolution of The Cretaceous Benue Trough. Nigeria. Journal of African Earth Science, 8, 251-282. http://dx.doi.org/10.1016/S0899-5362(89)80028-4

Blevins, R. L., Murdrock, L. W., \& Thomas, G. W. (1978). Effect of Lime Application on No-Till and Conventionally-Tilled Corn. Argon Journal, 70, 322-326.

Boynton, R. S. (1980). Chemistry and Technology of Limestone (2nd ed.). John Wiley and Sons.

Brady, N. K., \& Well R. R. (1999). The Nature and Properties of Soil (12 ${ }^{\text {th }}$ ed., pp 307-342). USA: Prentice Hall Inc.

Burke, K. C., Dessauvagie \& Whiteman, A. J. (1970). Geological History of the Benue Valley and Adjacent Areas. In African Geology (pp. 187-206). University of Ibadan Press.

Caires, E. F., Alleoni, L. R. F., Cambri, M. A., \& Barth, G. (2005). Surface Application of lime For Crop Grain Production under a No-Till System. Argon Journal, 97, 791-798.

Carroll \& Dorothy. (1970). Clay Minerals: A guide to their identification: Geological Survey of America, Special Paper, 126, 80.

Conyers, M. K., Heenan, D. P, Mcghie, W. J., \& Piole, G. P. (2003). Amelioration of Acidity with Time by Limestone under Contracting Tillage. Soil Tillage Resourecs, $72, \quad 85-94$. http://dx.doi.org/10.1016/S0167-1987(03)00064-3

Cratchely, \& Jones, G. P. (1965). An Interpretation of the Geology and Gravity anomalies Of the Benue Valley. Nigeria. Overseas Geological Survey Geophysical paper, 1. 
Cravotta, III C. A., \& Trahan, M. K. (1999). Limestone Drains to Increase pH and Remove Dissolved Metals from Acidic Mine Drainage. Journal of Applied Geochemistry, 14, 581-606. http://dx.doi.org/10.1016/S0883-2927(98)00066-3

Czernin, W. (1970). Cement Chemistry and Physics for Civil Engineers (2nd ed.). Wiesbadan Publication.

Department of Minerals and Energy. (2003). The dolomite and Limestone Industry in South Africa. Report R 14, 18.

Dunham, R. J. (1962). Classification of Carbonate Rocks according to Depositional Texture. In W. E. Ham (Ed.), Classification of Carbonate Rocks (pp. 108-121). Memo. American Association of Petroleum Geologist 1. Tulsa.

Emefurieta, W. O., \& Ekuajemi, V. O. (1995). Lime Products and Economic Aspects of Igbeti, Ososo and Jakura Marble Deposit in SW- Nigeria. Journal of Mining and Geology, 31(1), 79-89.

Erhuero, J. B. (1986). Inatalled Capacity Utilization Problems in the Nigerian Cement Industry: The case of Bendel Cement Company Limited. Unpublished M.Sc. Thesis, University of Benin.

Folk, R. L. (1959). Practical Petrograhic Classiication of limestones. American Association of Petroleum Geologist Bulletin, 43, 1-38.

Folk, R. L. (1962). Spectral Subdivision of Limestone Types. In W. E. Ham (Ed.), Classification of Carbonate Rocks (pp. 62-84). Memo. American Association of Petroleum Geologist 1. Tulsa.

Fredrick, O. A. et al. (2006). Macmilan Nigeria Secondary Atlas. Macmilan Publishers Ltd.

Friedman, G. M. (1964). Early Diagenesis and Lithification in Carbonate Sediments. Journal of Sedimentary Petrology, 34, 77 - 813.

Friedman, G. M. (1965). Terminology of Crystalization, Textures and Fabrics in Sedimentary Rocks. Journal of Sedimentary Petrology, 35, 643-655.

Friedman, H. (2000). Calcite. Retrieved June 23, 2005, from www.minerals.net

Godsey, C. B. (2005). Managing Soil Acidity in No-Till Cropping Systems. Ph.D. dissertation. Kansas State Univ., Manhathan.

Grant, N. K. (1971). The South Atlantic, Benue Trough and Gulf of Guinea Creteceous Tripple Junction. Geological Society of American Bulletin, $82, \quad 2295-2298$. http://dx.doi.org/10.1130/0016-7606(1971)82[2295:SABTAG]2.0.CO;2

Gwosdz. (1996). Nigeria. In H. R. Bosse, W. Gwosdz, W. Lorenz, R. W. Markwich, \& F. Wolff (eds.), limestone and Dolomite Resources of Africa. Geological Journal, D, 102, 326-333.

Ham, W. E., \& Pray, L. C. (1962). Modern Concepts and Classification of Rocks. In W. E. Ham (Ed.), Memo. American Association of Petroleum Geologist 1 (pp. 2-19). Tulsa.

Hamblin, W. K. (1992). Earth's Dynamic Systems (6th ed., pp. 63-112). Macmillan Publishing Company New York.

Harben, P. W. (1995). The Industrial Minerals HandBook (2nd ed., pp. 36-43). A guide to Markets, Specifications and Prices, Ontario.

Ibe, K. K. \& Ogezi, A. E. (1997). Chemical and Industrial Characteristics of the Carbonate Rock of the Late Maastrichtan Nsukka Formation in Ohafia Area of S.E Nigeria. $33^{\text {rd }}$ Annual Conference. Nigerian Mining and Geosciences Society. Jos. p. 11.

Iyah, R. O. (2004). Occurrence of Marl in Kano and Jigawa State as a Source of Fertilizer. Federal Ministry of Solid Mineral Resources Development, Geological Survey of Nigeria Agency, p. 30.

Katimon, A., Kassi, M. A., Sohaili, J., Othman, F., Latiff, A. A. A., \& Karim, A. T. A. (1999). Impact of Agicultural Drainage on Stream Water Quality. J. Teckno., 31, 67-77.

Leon, G. C. (1981). Certificate Physical and Human Geography for Senior Secondary Schools (Revised ed., pp. 18-24). Longman Group Limited, U.K.

Malaysian Water Association. (1994). Design Guidelines for Water Supply System. MWA, Kuala Lumpur.

Maurin, J. C., Benkhelil, J., \& Robineau, B. (1986). Fault Rocks of the Kaltunga Lineament North East, Nigeria and their Relationship with the Benue Trough. Journal of Geological Society, 143, 589-599. http://dx.doi.org/10.1144/gsjgs.143.4.0587 
Ministry of Solid Minerals Development. (2000). An Inventory of Solid Mineral Potentials of Nigeria. Prospectus for Investors. p. 15.

Nair, K. M., \& Ramanathan, R. M. (1984). Sedimentary Stratigraphy and Paleograhic Significance of Lower Cretaceous Gboko Limestone, Nigeria. Journal of Mining and Geology, 21(1\&2), 203-210.

Nuttal, C., \& Younger, P. L. (2000). Zinc Removal from Hard, Circum-Neutral Mine Waters Using a Novel Closed- Bed Limestone Reactor. Water Resources, 34(4), 1262-1268.

Nwachuckwu, S. O. (1972). Tectonic Evoluion of the Southern Portion of the Benue Trough. Nigeria. Nigerian Journal of Mining and Geology, 21, 203-210.

Obaje, N. G. (2009). Geology and Mineral Resources of Nigeria, Lecture Notes in Earth Sciences. Spinger-Verlag, Berlin, Heidelberg, 120, 57-68.

Obaje, N. G., Liqouis, B., \& Abba, S. I. (1994). Petrograhic, Composition and Depositional Environments of Cretaceous Coal Measures in the Middle Benue Trough of Nigeria. Intenational Journal of Coal Geology, 26, 233-260. http://dx.doi.org/10.1016/0166-5162(94)90012-4

Offodile, M. E. (1976). The Geology of the Middle Benue Nigeria. Special Publication of Paleontology Institute University Uppsala, 4(99), 1-166.

Offodile, M. E., \& Rayment, R. A. (1976). Stratigraphy of the Keana Awe Area of the Middle Benue Region of Nigeria. Bulletin Geological Institute University. Uppsala, 9, 37-66.

Ofoegbu, C. O. (1984). A Model for the Tectonic Evolution of the Benue Trough of Nigeria. Geologica Rundschau, 73, 1007-1008. http://dx.doi.org/10.1007/BF01820885

Ojo, A. M., Abimbola, A. F., Okunlola, O. A., \& Oguntoyi, F. I. (1996). Agro Geological Studies Of Limestone, Phosphate and Gypsum Occurrence in Dahomey Basin, SW Nigeria in Relation to Soil Acidity Amelioration, $35^{\text {th }}$ Annual Conference. Nigerian Mining and Geosciences Society, Abuja. p. 65.

Ola, S. A. (1977). Limestone Deposits and Small Scale Production of Lime in Nigeria. Engineering Geology, 11, 127-137. http://dx.doi.org/10.1016/0013-7952(77)90023-0

Olade, M. A. (1983). Raw Material Investigations for Cement Manufacture, Ibese, Ogun State. Unpublished. Consultancy Report, Ogun State Government. p. 70.

Petters, S. W. (1978). Stratigraphic Evolution of the Benue Trough and its implication For the Upper Cretaceous paleogeograghy of West Africa. Jounal of Geology, 86, 311-322. http://dx.doi.org/10.1086/649693

Philips, R. I., Folorunso, A. F., Nton, M. E., \& Oluwalaanu, J. A. (2009). Evaluation of Turonian Limestone Formation exposed at NIGERCEM-Quarry Nkalagu, Southeasthern Nigeria; A geochemical approach. Pacific Journal of Science and Technology, 10(2), 763- 771.

Umeshwar, P. (2003). Economic Geology (reprint, pp. 204-207). New Delhi: Satish Kumar Jain for C.B.C.

Wright, J. B., Hasting, D. A., Jones, W. B., \& Williams. (1985). Geology and Mineral Resources West Africa. (pp. 187). London, UK: Allen and Unwin.

Ziemkiewics, P. F., Skousen, J. G., Brant, D. L., Sterner, P. L., \& Lovett, R. J. (1997). Acid Mine Drainage Treatment with Armoured Limestone in Open-Limestone Channel. Journal of Environmental Quality, 26(4), 1017-1024. http://dx.doi.org/10.2134/jeq1997.00472425002600040013x 